\title{
USE OF A FORMULATED DIET FOR MUSSEL SPAT MYTILUS GALLOPROVINCIALIS (LAMARCK 1819) IN A COMMERCIAL HATCHERY
}

\author{
NANCY NEVEJAN, ${ }^{1 *}$ JONATHAN DAVIS, ${ }^{2}$ KELLY LITTLE ${ }^{2}$ AND ANNA KILIONA ${ }^{2}$ \\ ${ }^{1}$ INVE Technologies, Hoogveld 93, B-9200 Dendermonde, Belgium; ${ }^{2}$ Taylor Shellfish Farms, \\ 701 Broad Spit Road, Quilcene, Washington 98376
}

\begin{abstract}
In the present study we evaluated the musselspat feed MySpat formulated by INVE Technologies (Dendermonde, Belgium) in combination with small quantities of microalgae as a complete diet for young mussel seed Mytilus galloprovincialis (Lamarck 1819). Three different food levels were tested: a continuous algae supply over a period of $24 \mathrm{~h}$ of 150 cells $\mu \mathrm{l}^{-1}(\mathrm{Control}$ diet $1, \mathrm{C} 1), 75 \mu \mathrm{l}^{-1}$ (C 2) and 24 cells $\mu \mathrm{l}^{-1}$ (C 3). In three additional treatments $\mathrm{C} 2$ was supplemented with $2.8 \%$ and $\mathrm{C} 3$ with $2.8 \%$ and $4.3 \%$ MySpat respectively. Percentage was calculated on life weight (LW). Mussel spat belonging to treatments $\mathrm{C} 3+$ $2.8 \%$ MySpat and C 3+4.3\% MySpat gained almost twice as much weight as the mussels fed the nonsupplemented algae diet C 3 . There was no significant difference between the two supplementation levels, indicating that a level of $2.8 \%$ was sufficient. The mussel spat that received the supplement MySpat grew as fast as the animals that received 75 cells $\mathrm{l}^{-1}$ being $702 \%$ increase in wet weight (WW) in $3 \mathrm{wk}$, so the same result was obtained with only $1 / 3$ of the algae. This is interesting when one considers that the mussel spat in the last week of the experiment received $95 \%$ dry weight (DW) formulated feed and only $5 \% \mathrm{DW}$ algae. The growth was well balanced between shell growth and increase of tissue weight, because the organic matter content of the animals was equal to or even higher than the positive control animals. Mussel seed on the $\mathrm{C} 3$ diet had a fatty acid methyl ester (FAME) content of $6.6 \mathrm{mg} \mathrm{gDW}^{-1}$, whereas this content quadrupled to $28.1 \mathrm{mg} \mathrm{gDW}^{-1}$ when $2.8 \%$ MySpat was given in addition to the algae diet, reaching levels even higher than for the positive control treatment. The fatty acid composition reflected the diet-composition, hereby proving the ingestion and assimilation of the diet. It is suggested that mussel seed regulate arachidonic acid (ARA) levels and keep the absolute amount in their tissues at $0.4 \mathrm{mg} \mathrm{gDW}^{-1}$.
\end{abstract}

KEY WORDS: mussel, formulated diet, artificial diet, bivalves, algae replacement, Mytilus galloprovincialis

\section{INTRODUCTION}

Mussels have become a popular consumption product in the last 10 years. World production of mussels steadily increased over the past decades, from about 700,000 tons in the 1970 s, to 900,000 tons in the 1980s, to 1.4 million tons in the 1990s and 1.8 million tons at present. Capture production of mussels has been relatively stable for a long time at about 200,000 tons. Aquaculture of mussels, on the other hand, has continuously increased reaching in 2003 almost 1.6 million tons (FAO Fishstat). The dependence on wild seed to replenish the culture plots is becoming a serious problem in Europe. The unpredictable recruitment of wild seed and the "green" lobby's antagonistic view that the industry out-competes wildlife that feed on mussels, make the need for hatchery produced seed even more urgent (Edwards 2004).

At present, the hatchery rearing of bivalves relies on the mass production of microalgae. Bivalves are often fed multispecies algal diets, because they usually support better growth and development than single-species diets (De Pauw \& Persoone 1988). Coutteau \& Sorgeloos (1992) identified the mass production of live algae as a major bottleneck in bivalve hatcheries and nurseries. The algae production costs comprise up to $30 \%$ of the hatchery operation costs. Furthermore, algae cultures are often subjected to contamination and variable nutritional value. Because of all the above-mentioned problems, researchers and culturists are looking for low-cost alternatives. At present, most of the alternative diets such as spray-dried microalgae, microcapsules, yeast-based diets, lipid microspheres, and emulsions cannot fully replace the live microalgae, but are very useful as a partial substitute or as a back-up diet (Coutteau et al. 1994, Heras et al. 1994, Laing \& Lopez-Alvarado 1994, Knauer \& Southgate 1997a, Knauer \& Southgate 1997b, Pérez Camacho

\footnotetext{
*Corresponding author. E-mail: n.nevejan@inve.be
}

et al. 1997, Caers et al. 1998, Langdon \& Önal 1999, Nevejan et al. 2003, Pernet et al. 2004, Fernández-Reiriz et al. 2006, Önal et al. 2006). Langdon \& Önal (1999) on the other hand were able to obtain the same growth in mussel seed (M. galloprovincialis) when the algae were replaced with an equivalent amount in dry weight (DW) of Schizochitrium mixed with ground Spirulina platensis. Davis and Cambell (1998) also observed up to $3.2 \%$ increase in live weight in M. galloprovincialis provided with a $100 \%$ diet of formulated feed based on Schizochitrium compared with controls providing a live algae diet in feeding trials conducted under commercial conditions.

In the present study we have evaluated the mussel spat feed MySpat formulated by INVE Technologies (Dendermonde, Belgium) in combination with small quantities of microalgae as a complete diet for young mussel seed (Mytilus galloprovincialis).

\section{MATERIALS AND METHODS}

The experiment was carried out in a commercial bivalve hatchery (Taylor Resources Inc., Quilcene, WA). The formulated feed MySpat is a white microencapsulated very fine powder with a particle size range as shown in Table 1 . The feed has a typical proximate composition of $36 \%$ protein, $15 \%$ lipids, and $27 \%$ carbohydrate. Lipids originate from fish oils whereas the proteins are from vegetal origin (source INVE).

Diploid mussel seed ( $3 \mathrm{wk}$ postset with a mean shell length of $718 \mu \mathrm{m}[ \pm 154])$ was collected from an outdoor nursery at the Taylor Resources facility on 25th of January 2006 and maintained inside the hatchery in 36 downwelling silos divided over 2 rectangular shaped tanks (Table 2). Every tank was subdivided into three watertight units, each unit containing six replicate silos. Each unit was continuously supplied with fresh filtered $(2-\mu \mathrm{m})$ seawater (from a common header tank) and its specific 
TABLE 1.

Particle size distribution of formulated feed "MySpat."

\begin{tabular}{cc}
\hline \hline Size Range $(\boldsymbol{\mu m})$ & $\boldsymbol{\%}$ \\
\hline$<10$ & 28 \\
$10-20$ & 30 \\
$20-30$ & 17 \\
$30-100$ & 25 \\
\hline
\end{tabular}

Source: INVE.

feed mixture from its feeding tank (6 feedings tanks in total). One gram of spat contained an estimated 10,000 animals at the start of the experiment. Each silo (height $30.5 \mathrm{~cm}$, diameter 15.2 $\mathrm{cm}$ ) had a bottom sieve of $180 \mu \mathrm{m}$ and was initially stocked with $3.5 \mathrm{~g}$ of seed, or approximately 35,000 mussels. The feeding trial was conducted over a 3 wk period. There were six treatments with six replicate silos ( 3 treatments per tank, Table 2 ). Three different food levels were tested: a continuous algae supply over a period of $24 \mathrm{~h}$ of 150 cells $\mu \mathrm{l}^{-1}$ (Control diet 1, C 1), $75 \mu \mathrm{l}^{-1}$ (C 2) and 24 cells $\mu 1^{-1}$ (C 3 ). In three additional treatments $C 2$ was supplemented with $2.8 \%$ and C 3 with $2.8 \%$ and $4.3 \%$ MySpat respectively. Percentage was calculated on life weight (LW). Control diet 1 (C 1) represented an "in excess" algae diet (positive control), whereas $\mathrm{C} 2$ an optimal diet that could be supplied by the hatchery's algae production system under optimal conditions. C 3 was the negative control diet where retarded growth was expected. The temperature for both tanks was $18.3^{\circ} \mathrm{C} \pm 0.7^{\circ} \mathrm{C}$.

The algae mixture consisted of Isochrysis galbana (T-Iso): Chaetoceros muelleri (Chagra) in a ratio 25:75 (based on cell count). The algae were grown in a semicontinuous bag system and harvested in the exponential phase. The algae concentration was measured daily with a particle counter Coulter Electronics. The algae ratio did not change during the experiment. The quantity of MySpat was adjusted weekly to a new mussel biomass in each treatment. There were 5.17 seawater exchanges daily in the nursery tanks and all rations supplied to mussels were multiplied with that factor to account for loss. The amounts of algae and formulated diet for each treatment were combined in a feeding tank and adjusted with filtered seawater to obtain a daily starting volume of $180 \mathrm{~L}$. Aeration in the feeding tanks was provided for mixing seawater and diet and prevented any significant sedimentation. The feed suspension was continuously pumped into the corresponding unit at a rate of $125 \mathrm{~mL} \mathrm{~min}^{-1}$.

TABLE 2.

Six treatments of the feeding experiment with $M$. galloprovincialis.

\begin{tabular}{lccc}
\hline \hline Treatment $(\boldsymbol{n}=\mathbf{6})$ & Tank & $\begin{array}{c}\text { Algae Concentration } \\
\left(\text { cells } \boldsymbol{\mu l}^{-\mathbf{1}} \text { ) }\right.\end{array}$ & MySpat \\
\hline C 1 & 1 & 150 & 0 \\
C 2 & 1 & 75 & 0 \\
C 3 & 2 & 24 & 0 \\
C 2 + 2.8\%MySpat & 1 & 75 & $2.8 \%$ mussel LW \\
C 3 + 2.8\%MySpat & 2 & 24 & $2.8 \%$ mussel LW \\
C 3 + 4.3\%MySpat & 2 & 24 & $4.3 \%$ mussel LW \\
\hline
\end{tabular}

The sieves at the bottom of the silos were cleaned daily. The feeding tanks were rinsed with freshwater every day and washed with a disinfectant solution (mixture of peroxide and peracetic acid) every two days. Feed distribution lines were flushed every 2 days with the disinfectant. The experimental tanks were cleaned and disinfected once a week.

To weigh the spat weekly, all animals were removed from their silo by spraying them off the sieve and walls with a high pressure freshwater hose. Mussels were collected on a small, pretared sieve and towel-dried with absorbent paper and weighed.

After three weeks and following the final live weight measurement for mussels in each of the replicate silos, the replicates of one treatment were combined to have enough sample for all the analyses. Samples were taken for counting the number of animals per gram, for length measurement by image analysis (Clemex Vision software on preserved samples in lugol:acetic acid solution), for biochemical analysis and for fatty acid analysis (preserved at $-80^{\circ} \mathrm{C}$ until analysis). To estimate the number of mussels per gram, a total of three subsamples were taken per treatment, weighing between 0.540 and $0.758 \mathrm{~g}$. Each subsample was counted and a conversion was made to calculate the number per gram. The average and standard deviation was calculated for each treatment.

Dry weight was determined to be the weight after drying at $63^{\circ} \mathrm{C}$ for $48 \mathrm{~h}$. Crude ash was determined to be the residue remaining after heating at $450^{\circ} \mathrm{C}$ for $24 \mathrm{~h}$ in a muffle oven. Organic matter (OM) was calculated as the difference between DW and ash content. Crude protein was determined based on the nitrogen $(\mathrm{N})$-content, determined according to the Kjeldahl method (EG 1993). Crude fat was determined after hydrolysis (EG 1998). The carbohydrate level was estimated by subtracting the protein and lipid content from the OM content, assuming that the fiber content was negligible.

\section{Fatty Acid Analysis}

Fatty acid analysis was carried out on the mussel seed and formulated feed MySpat. Total lipids were directly extracted from the sample with the solvent mixture methanol/toluene $(3: 2, \mathrm{v} / \mathrm{v})$. Esterification of fat was accomplished by the addition of freshly prepared acetylchloride-methanol (1:20) and leaving the reaction to take place for $1 \mathrm{~h}$ in a boiling water bath. Once cooled, fatty acid methyl esters (FAMEs) were extracted with hexane. After evaporation of the solvent, the FAMEs were prepared for injection by redissolving them in iso-octane $(2 \mathrm{mg}$ $\mathrm{ml}^{-1}$ ). Quantitative determination was done by a Agilent $6890 \mathrm{~N}$ gas chromatograph equipped with an autosampler. Injections were performed on-column into a DB23 $60 \mathrm{~m}$ capillary column with a diameter of $0.25 \mathrm{~mm}$ and a layer thickness of $0.25 \mu \mathrm{m}$ connected to a $2.5 \mathrm{~m}$ methyl deactivated precolumn. The carrier gas was $\mathrm{H}_{2}$ at a pressure of $230 \mathrm{kPa}$ and the detection mode FID. The oven was programmed to rise from the initial temperature to $50^{\circ} \mathrm{C}$ and stay for $1 \mathrm{~min}$, from $50^{\circ} \mathrm{C}$ to $175^{\circ} \mathrm{C}$ at a rate of $25^{\circ} \mathrm{C}$ $\mathrm{min}^{-1}$, from $175^{\circ} \mathrm{C}$ to $230^{\circ} \mathrm{C}$ at $4^{\circ} \mathrm{C} \mathrm{min}^{-1}$ and to stay at $230^{\circ} \mathrm{C}$ for 15 min. Identification was based on standard reference mixtures (Nu-Chek-Prep, Inc., Elysian, MN, USA). Integration and calculations were done with the software program Chemstation.

\section{Data Analysis}

The homogeneity of variances of means was tested by the Univariate Test (Levene test). Significant differences were 
detected using the one-way ANOVA, $P$ being set at 0.05 . The Tukey HSD test was used for posthoc comparison.

\section{RESULTS}

\section{Mussel Seed Weight}

Visual evaluation of the mussel seed revealed no mortality in any of the treatments.

The weight of the mussel spat doubled every week for all treatments, except for $\mathrm{C} 3$ (Fig. 1). Mussel spat receiving C 3 was growing significantly slower throughout the experiment.

There was no significant difference in weight between seed receiving 150 cells $\mu 1^{-1}$ (C 1) and 75 cells $\mu^{-1}$ (C 2) until week three. A supplement of MySpat to $\mathrm{C} 2$ at that stage had no effect (C $2+2.8 \%$ MySpat). In the third week however, the diet C 2 became limiting and led to a slower growth rate than for $\mathrm{C} 1$. The addition of $2.8 \%$ MySpat however allowed a similar growth as for $\mathrm{C} 1$.

The treatments C $3+2.8 \%$ MySpat and C $3+4.3 \%$ MySpat were not significantly different throughout the experiment. Both treatments resulted in a weight gain that equaled almost twice the weight of the nonsupplemented C 3 diet. Throughout the experiment, the mussel spat of both treatments had the same growth rate as the ones that received the $\mathrm{C} 2$ treatment.

\section{Mussel Seed Size}

The histogram shown later (Fig. 2) illustrates the size distribution of mussel spat for the different treatments. In terms of size, spat of C 1 treatment grew best $(58 \%<2,000 \mu \mathrm{m})$, whereas diet C 3 led to the smallest animals $(95 \%<2,000 \mu \mathrm{m})$. Only small differences were noticed between the other 4 treatments.

\section{Biochemical Analysis}

As the amount of supplied algae goes down, the \% OM content in mussel spat goes down as well (Fig. 3). The \% OM content for mussel spat that received C $1\left(150\right.$ cells $\left.\mu \mathrm{l}^{-1}\right), \mathrm{C} 2(75$ cells $\left.\mu \mathrm{l}^{-1}\right)$ and C $3\left(24\right.$ cells $\left.\mu \mathrm{l}^{-1}\right)$ was $25.6 \%, 22.9 \%$, and $19.1 \%$ respectively. On the other hand, the supplementation of MySpat to the C 3 diet allowed the spat to maintain their OM

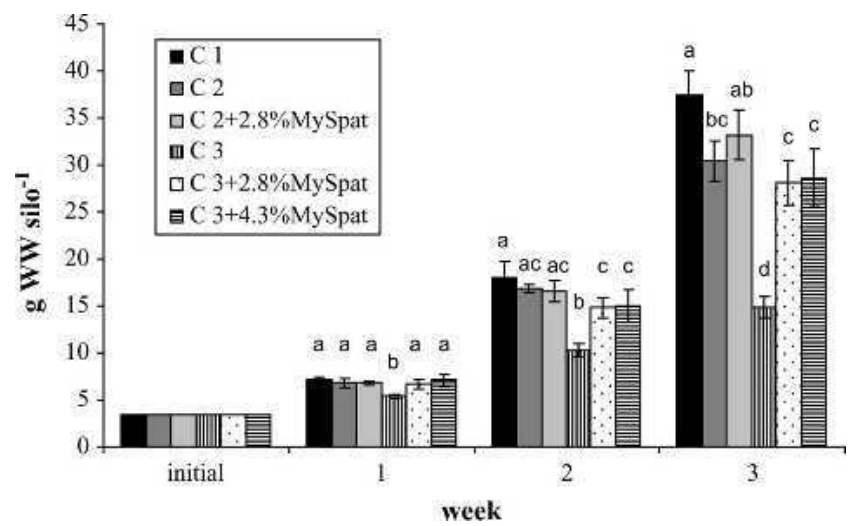

Figure 1. Average weight (g) of mussel seed (M. galloprovincialis) per silo, measured on weekly basis $(n=6) . C 1: 150$ cells $\mu l^{-1}$; $C$ 2: 75 cells $\mu l^{-1}$; C 3: 24 cells $\mu^{-1}$; columns with different letters are significantly different (Tukey HSD test, $P<0.001$ ).

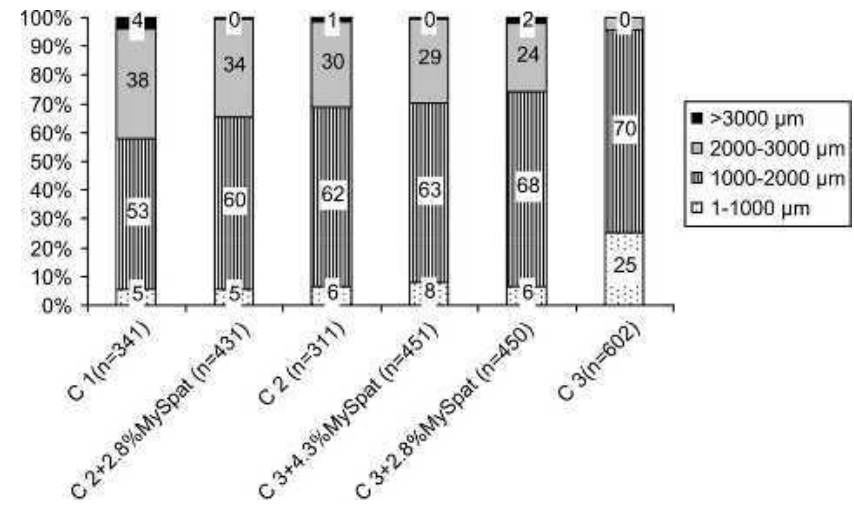

Figure 2. Size distribution ( $\mu \mathrm{m})$ of mussel spat (M. galloprovincialis) for 6 different treatments after $3 \mathrm{wk}(n=311-602) . \mathrm{C} 1: 150$ cells $\mu \mathrm{I}^{-1} ; \mathrm{C} 2: 75$ cells $\mu \mathrm{l}^{-1}$; C 3: 24 cells $\mu \mathrm{l}^{-1}$.

content to the level of the $\mathrm{C} 1$ treatment. The highest level of $\mathrm{OM}$ is found in the animals that received $\mathrm{C} 2+2.8 \%$ MySpat.

Proximate analysis of the formulated feed (Table 3) showed a relative high carbon content in comparison with the mixed algae diet (data algae collected from literature). Protein and lipid content on the other hand seemed quite similar between the diets.

The protein level of the mussel spat that received a pure algae diet (C 1, C 2, C 3) varied between $76.2 \%$ to $82.5 \%$ on OM, whereas the supplementation of MySpat lowered the protein content in spat to $64.5 \%$ to $67.6 \%$ (Fig. 4). Crude lipid levels appeared not to be affected so much by the diets. The estimated carbohydrate level is also included in the graph and amounts to $2.0 \%$ to $12.6 \%$ and $15.9 \%$ to $22.3 \%$ for nonsupplemented and supplemented diets respectively.

\section{FAME Results}

Table 4 shows the lipid composition of the diets, more specifically a selection of fatty acids that are physiologically important and/or show major differences between the diets. MySpat has a higher percentage of oleic acid (18:1n-9) and linoleic acid (18:2n-6) than either T-Iso and Chagra.

With less algae being fed to the animals, the total FAME content in mussel spat decreases from 17.8-13.4-6.6 $\mathrm{mg} \mathrm{gDW}^{-1}$

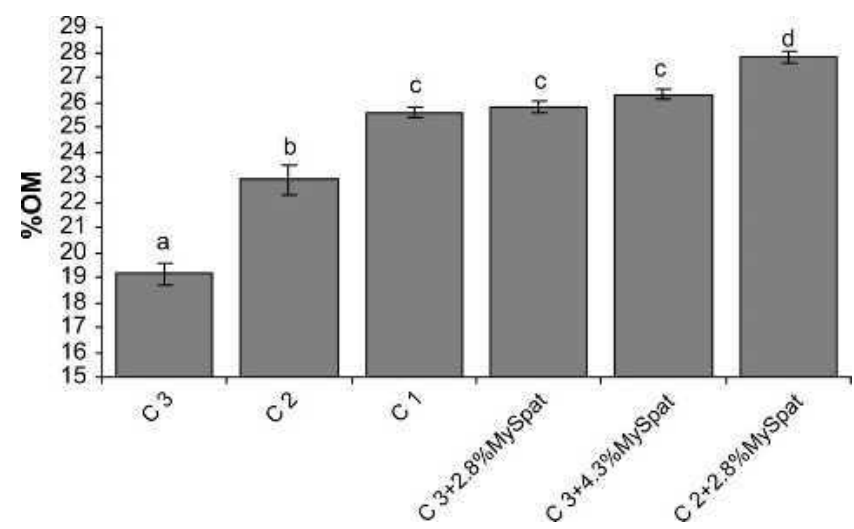

Figure 3. Organic matter content (\% on DW, $n=3)$ of mussel spat ( $M$. galloprovincialis) after $3 \mathrm{wk}$ of treatment. $\mathrm{C} 1: 150$ cells $\mu^{-1} ; \mathrm{C} 2: 75$ cells $\mu^{-1}$; C 3: 24 cells $\mu l^{-1}$; columns with different letters are significantly different (Tukey HSD test, $P<0.001$ ). 
TABLE 3.

Protein, lipid and carbohydrate composition (\%DW) of the formulated feed MySpat and the algae Isochrysis galbana (T-Iso) and Chaetoceros muelleri (Chagra).

\begin{tabular}{lllc}
\hline \hline \%/DW & Protein & \multicolumn{1}{c}{ Lipid } & Carbohydrates \\
\hline MySpat $^{1}$ & 36 & 15 & 27 \\
T-Iso $^{2}$ & $33-43$ & $23-25$ & $8.7-9.2$ \\
Chagra $^{3,4}$ & $43.8 \pm 3.3$ & $21-25.9$ & $12.3 \pm 0.5$ \\
\hline
\end{tabular}

${ }^{1}$ INVE; ${ }^{2}$ Whyte 1987; ${ }^{3}$ D'Souza \& Loneragan 1999; ${ }^{4}$ Milke et al 2004.

for C 1, C 2 and C 3 respectively (Table 5). The content of fatty acids EPA and DHA decreases as well, but the decline in DHA is more conservative, leading to an increase in the DHA/EPA ratio for the treatment $\mathrm{C} 3$ compared with $\mathrm{C} 1$ and $\mathrm{C} 2$. The supplementation of MySpat to the $\mathrm{C} 2$ diet results in a $56 \%$ total FAME increase compared with the nonsupplemented $\mathrm{C} 2$ diet, whereas the addition of MySpat to the $\mathrm{C} 3$ diet quadrupled the FAME content in mussel spat compared with the nonsupplemented C 3 diet. Despite that, the DHA/EPA ratio for the three supplemented diets remained constant at 1.4. The ARA content in mussel seed for all treatments stayed the same at $0.4 \mathrm{mg}$ $\mathrm{gDW}^{-1}$ whereas the content of $16: 0$ and especially $18: 1 \mathrm{n}-9$ fluctuated significantly.

\section{DW of the Different Diets}

To calculate the total amount of feed that was given per treatment (Table 6), the DW of MySpat was accepted to be $100 \%$. The DW of the algae mixture was calculated to be $30 \mathrm{pg}$ cell $^{-1}$ based on earlier DW measurements at the hatchery and literature review (Whyte 1987, Helm et al. 2004, Milke et al. 2004). The amount of feed was determined for the six silos together belonging to one treatment.

For the nonsupplemented algae diets, the total amount of feed remained constant in the course of the experiment, being 8.4, 4.2, and $1.4 \mathrm{gDW} \mathrm{gay}^{-1}$ for $\mathrm{C} 1, \mathrm{C} 2$, and $\mathrm{C} 3$ respectively. The amount of MySpat on the contrary was adjusted weekly to a new mussel live weight so that the total amount of feed for the supplemented diets increased weekly. The total daily amount of feed calculated per gram LW decreases with time for all treatments, because a constant amount of algae was given to a growing biomass of mussel seed. This is illustrated more in

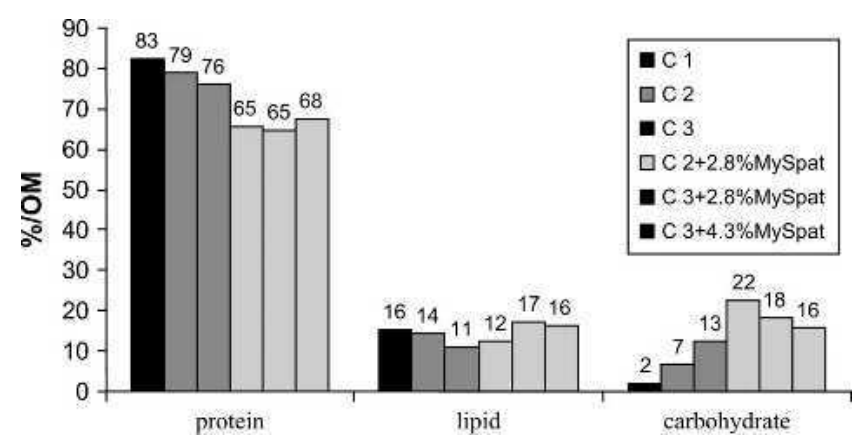

Figure 4. Protein, lipid, and carbohydrate level of mussel spat ( $M$. galloprovencialis) after 3 wk of experiment $(n=1) . C 1: 150$ cells $\mu^{-1}$; C 2: 75 cells $\mu l^{-1}$; C 3: 24 cells $\mu l^{-1}$.
TABLE 4.

Selection of the fatty acid composition of the formulated feed MySpat ${ }^{\circledR}$ and the algae Isochrysis galbana T-Iso and Chaetoceros muelleri (Chagra).

\begin{tabular}{lccc}
\hline \hline Fatty Acid (\%area) & MySpat $^{\mathbf{1}}$ & T-Iso $^{2,3,4,5}$ & Chagra $^{\mathbf{4 , 5 , 6}}$ \\
\hline $16: 0$ & 17.9 & $9.9-19.7$ & $5.8-15.4$ \\
18:1n-9 & 21.2 & $11.3-17.6$ & $0.5-0.8$ \\
18:2n-6 & 12.4 & $2.2-3.8$ & $0.5-0.9$ \\
ARA & 0.5 & $0-0.8$ & $1.5-7.4$ \\
EPA & 6.9 & $0.3-0.6$ & $12.0-23.3$ \\
DHA & 8.18 & $7.9-13.7$ & $1.8-2.2$ \\
DHA/EPA & 1.2 & $14.7-15.5$ & $0.08-0.15$ \\
FAME (\% total lipids) & 70.3 & $41.3-52.5$ & $53.7-75.8$ \\
\hline
\end{tabular}

${ }^{1}$ Analysis from this study; ${ }^{2}$ Albentosa et al. 1994; ${ }^{3}$ Albentosa et al. 1996; ${ }^{4}$ D'Souza \& Loneragan 1999; ${ }^{5}$ Robert et al. 2004; ${ }^{6}$ Milke et al. 2004.

detail in Figure 5 for treatment $\mathrm{C} 2$ and $\mathrm{C} 3+2.8 \%$, two diets that resulted in equal growth performance.

As the animals gained weight, the amount of algal feed expressed as DW on mussel LW decreased in the course of the experiment from $64-8 \mathrm{mgDW} \mathrm{gLW}^{-1} \mathrm{day}^{-1}$ for $\mathrm{C} 3+$ $2.8 \%$ MySpat and from 200-23 mgDW gLW $\mathrm{gLy}^{-1}$ for C 2. The contribution of MySpat remained constant at $144 \mathrm{mgDW}$ $\mathrm{gLW}^{-1} \mathrm{day}^{-1}$. The contribution of algae in the total amount of feed (DW) given to the animals of treatment C 3+2.8\% MySpat decreased from $31 \%$ to $5 \%$.

\section{DISCUSSION}

The downwelling flow-through system proved to be very suitable for mussel spat, because excellent growth was recorded when nutrition was adequate (i.e., the weight of the mussel seed doubled every week for all treatments except for $\mathrm{C} 3$ ). The growth of mussels in the $\mathrm{C} 3$ treatment lagged from the start, so the algae ratio of 24 cells $\mu \mathrm{l}^{-1}$ provided a good negative control. Until the third week, 75 cells $\mu 1^{-1}$ (C 2) fulfilled the nutritional needs of the growing seed, because there was no significant difference with the seed receiving 150 cells $\mu l^{-1}$ (C 1). A supplement of MySpat to $\mathrm{C} 2$ at that stage therefore had no effect and the three treatments C 1, C 2, and C 2+2.8\% MySpat had similar growth patterns. In the third week however, the diet C 2 became limiting (outflow algal concentration decreased from 35-9 cell $\mu \mathrm{l}^{-1}$ ) and the addition of 2.8\% MySpat at that point boosted growth to the level of $\mathrm{C} 1$.

The treatments C $3+2.8 \%$ MySpat and C $3+4.3 \%$ MySpat were not significantly different throughout the experiment, indicating that a supplementation level higher than $2.8 \%$ did not yield better results. Both treatments resulted in a weight gain that equaled almost twice the weight of the nonsupplemented C 3 diet. Diet C 3 was the only treatment with significantly more animals per gram than all the other treatments, $2,399( \pm 104)$ versus $1,124( \pm 100)$ respectively $(F(5,12)=$ 137.5, $P<0.001)$.

The mussel spat of treatment C $3+2.8 \%$ MySpat that received 24 cells $\mathrm{ml}^{-1}$ gained weight as fast as the animals that received a constant inflow of 75 cells ml $^{-1}$, so the same result was obtained with only $1 / 3$ of the algae. This fact becomes even more interesting when one considers that the mussel spat 
Formulated Diets for Bivalves

TABLE 5.

The fatty acid composition $(n=1)$ of the mussel seed (M. galloprovincialis) belonging to six different treatments $\left(\mathrm{mg} \mathrm{gDW}^{-1}\right.$ and \%area).

\begin{tabular}{|c|c|c|c|c|c|c|c|c|}
\hline Fatty Acid & $16: 0$ & $18: 1 n-9$ & $18: 2 n-6$ & ARA & EPA & DHA & DHA/EPA & Total FAME \\
\hline \multicolumn{9}{|l|}{ mg gDW-1 } \\
\hline $\mathrm{C} 1$ & 2.9 & 1.0 & 1.4 & 0.4 & 1.9 & 2.4 & 1.3 & 17.8 \\
\hline $\mathrm{C} 2$ & 2.7 & 0.8 & 0.9 & 0.4 & 1.2 & 1.8 & 1.6 & 13.4 \\
\hline C 3 & 1.4 & 0.2 & 0.4 & 0.3 & 0.6 & 1.1 & 2.0 & 6.6 \\
\hline C $2+2.8 \%$ MySpat & 3.2 & 1.9 & 2.1 & 0.4 & 2.0 & 2.9 & 1.4 & 21.0 \\
\hline C $3+2.8 \%$ MySpat & 4.6 & 2.7 & 3.1 & 0.4 & 2.9 & 4.2 & 1.4 & 28.1 \\
\hline C $3+4.3 \%$ MySpat & 4.0 & 2.7 & 2.8 & 0.4 & 2.6 & 3.7 & 1.4 & 25.6 \\
\hline \multicolumn{9}{|l|}{$\%$ area } \\
\hline C 1 & 15.8 & 4.9 & 6.6 & 1.9 & 9.3 & 11.2 & 1.3 & 88.4 \\
\hline $\mathrm{C} 2$ & 18.8 & 5.1 & 5.9 & 2.2 & 7.4 & 11.0 & 1.6 & 86.9 \\
\hline C 3 & 18.4 & 3.0 & 4.6 & 3.0 & 7.0 & 13.1 & 2.0 & 81.8 \\
\hline C $2+2.8 \%$ MySpat & 14.9 & 7.7 & 8.9 & 1.5 & 8.3 & 11.5 & 1.4 & 88.5 \\
\hline C $3+2.8 \%$ MySpat & 16.1 & 8.5 & 9.8 & 1.4 & 9.1 & 12.5 & 1.4 & 89.8 \\
\hline C $3+4.3 \%$ MySpat & 15.6 & 9.3 & 9.6 & 1.4 & 8.9 & 12.0 & 1.4 & 90.1 \\
\hline
\end{tabular}

C 1: 150 cells $\mu \mathrm{l}^{-1}$; C 2: 75 cells $\mu \mathrm{l}^{-1}$; C $3: 24$ cells $\mu \mathrm{l}^{-1}$.

received $95 \%$ formulated feed on DW basis by week three and only $5 \%$ DW algae. The OM content of the MySpatsupplemented treatment was equal or even higher than the OM content of the "in excess" diet C1, hereby demonstrating that not only the shell was growing but also the tissue content.

Langdon and Önal (1999) reported that mussel spat $M$. galloprovincialis that received a quarter ration of living algae plus a mixed supplement of 50:50\% w:w Schizochytrium(SZ): Spirulina platensis $(\mathrm{Sp})$ for a period of $3 \mathrm{wk}$, grew significantly faster than mussels fed a full live algal ration (200 algal cells $\mu \mathrm{l}^{-1}$ day $^{-1}$, control treatment). They also demonstrated that it was possible to completely replace a living algal diet with spraydried diets based on SZ, mixed with ground Sp (70:30\% w:w SZ:GSp) or with ground Sp and Haematococcus $(\mathrm{H})$ (25:50:25\% w:w H:Sz:GSp). One should consider however that the $\%$ increase in wet weight was only $130 \%$ to $150 \%$ for the control treatment and between $200 \%$ to $240 \%$ for the spray-dried diets. In our study, the $\%$ increase in wet weight obtained with the diet C $3+2.8 \%$ MySpat was $702 \%$. For comparison, the treatments $\mathrm{C} 1$ and $\mathrm{C} 2$ had an increase of $968 \%$ and $768 \%$ respectively.

Whyte et al. (2002) on the other hand obtained good growth with juvenile M. galloprovincialis when they were fed a mix of live algae (Chaetoceros muelleri:Isochrysis galbana 1:1 (w:w) and Schizochytrium at 1:1 (w:w) for 120 days.

Davis and Cambell (1998) fed M. galloprovincialis diets varying between $33 \%$ and $100 \%$ Schizochytrium with the results that mussels exhibited up to $3.2 \%$ weight gain per day maintained on the $100 \%$ Schizochytrium based formulated diet. This compared with a control (live algae) diet weight gain of $3.9 \%$ per day over the 30-day trial period. Other combinations offered a similar advantage. Supplementing the formulated feed for live algae offered a substitution that resulted in approximately equivalent weight gain observed in mussels supplied live microalgae alone. The physical characteristics of the product however were not satisfying (pers. comm.).

The question remains why the animals of C $3+2.8 \%$ MySpat did not achieve the same growth as the animals of $\mathrm{C} 1$ because they received a multiple amount of feed in terms of DW. A possible reason could be the relative high content in carbohydrates and relatively low content in protein. Figure 4 demonstrated a decline in protein content in mussel spat that received the INVE supplement MySpat. Kreeger \& Langdon (1994) used mixed diets with T-Iso and protein-walled microcapsules and demonstrated that growth rates of juvenile M. trossulus (Gould

TABLE 6.

Total amount of feed given to mussel spat (M. galloprovincialis) during 3 wk of experiment, calculated as gDW day ${ }^{-1}$ and as mgDW $\mathrm{gLW}^{-1}$ day $^{-1}$.

\begin{tabular}{|c|c|c|c|c|c|c|c|c|}
\hline \multirow[b]{2}{*}{ Treatment } & \multicolumn{4}{|c|}{ Total (gDW day ${ }^{-1}$ ) } & \multicolumn{4}{|c|}{ mgDW g LW ${ }^{-1}$ day $^{-1}$} \\
\hline & Start & Week 1 & Week 2 & Week 3 & Start & Week 1 & Week 2 & Week 3 \\
\hline $\mathrm{C} 1$ & 8.4 & 8.4 & 8.4 & 8.4 & 400 & 197 & 78 & 37 \\
\hline $\mathrm{C} 2$ & 4.2 & 4.2 & 4.2 & 4.2 & 200 & 102 & 41 & 23 \\
\hline C 3 & 1.4 & 1.4 & 1.4 & 1.4 & 64 & 42 & 22 & 15 \\
\hline C $2+2.8 \%$ MySpat & 7.3 & 7.3 & 10.2 & 18.6 & 344 & 247 & 186 & 165 \\
\hline C $3+2.8 \%$ MySpat & 4.4 & 4.4 & 7.1 & 14.2 & 208 & 178 & 159 & 152 \\
\hline C $3+4.3 \%$ MySpat & 6.0 & 6.0 & 10.8 & 21.4 & 286 & 253 & 237 & 230 \\
\hline
\end{tabular}

C 1: 150 cells $\mu 1^{-1}$; C 2: 75 cells $\mu 1^{-1}$; C $3: 24$ cells $\mu 1^{-1}$. 


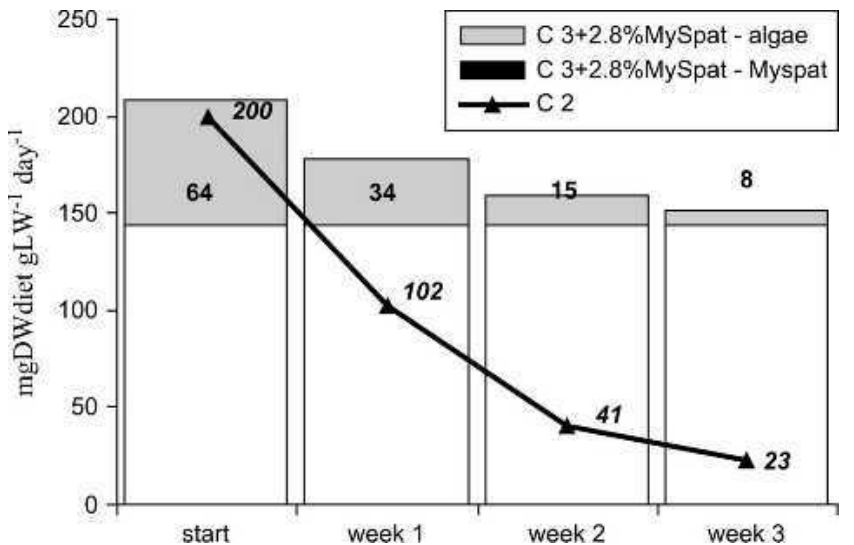

Figure 5. Evolution of the algal contribution in selected treatments $\left(\mathrm{mgDW} \mathrm{gLW}^{-1} \mathrm{day}^{-1}\right)$ during 3 wk of experiments. C 2: 75 cells $\mu \mathrm{l}^{-1}$; C 3: 24 cells $\mu \mathrm{l}^{-1}$.

1860) were positively correlated with dietary protein content over the range $27.8 \%$ to $42.6 \% \mathrm{w}$ : w protein. Whyte et al. (2002) observed that the dietary protein of a $100 \%$ Schizochytrium diet is less effective than that in live microalgae at providing available amino acids and therefore leads to less energy competent mussels and slower growth. Langdon \& Önal (1999) claim that the beneficial effect of adding Spirulina platensis to Schizochytrium may have been because of the high protein content of Spirulina $(60 \%$ of DW).

The supplementation of MySpat to the $\mathrm{C} 2$ diet resulted in a total FAME increase from $13.4 \mathrm{mg} \cdot \mathrm{gDW}^{-1}$ to $21 \mathrm{mg} . \mathrm{gDW}^{-1}$, whereas the addition of MySpat to the $\mathrm{C} 3$ diet quadrupled the FAME content in mussel spat from $6.6-25.6 \mathrm{mg}_{\mathrm{gDW}} \mathrm{gD}^{-1}$. On the other hand, the total lipid content in mussel spat amounted to $2.1 \%$ (C 3), 3.2\% (C 2), 3.5\% (C 2+2.8\% MySpat), 4.0\% (C 1), $4.4 \%$ (C $3+2.8 \%$ MySpat), and 4.7\% (C $3+4.3 \%$ MySpat) on DW. This means that the FAME content expressed as percentage fat increased significantly when MySpat was supplemented to the mussel spat: from $33.3 \%$ to $55.3 \%$ and $63.6 \%$ for $\mathrm{C} 3$, C $3+4.3 \%$ MySpat, and C $3+2.8 \%$ MySpat respectively and from $40.6-60 \%$ for C 2 and C $2+2.8 \%$ MySpat. This reflects the higher FAME content of the formulated diet and confirms the assimilation of the diet into the tissues. It is unclear what the consequences are on the content of other fat sources such as sterols, because no such analysis was carried out.

The relative fatty acid profile ( $\%$ area) of mussel seed receiving the natural algal diet $\mathrm{C} 1$ and the formulated diet $\mathrm{C} 3+$ $2.8 \%$ MySpat was very comparable, except for the increase in oleic and linoleic acid with $73 \%$ and $48 \%$ respectively. The amount of these fatty acids in mussel tissue reflected the amount offered by the diet. The DHA/EPA ratio in both diets was very similar (1.3 vs. 1.4), indicating that the artificial diet was appropriately formulated in that respect. Very interesting on the other hand is the behavior of ARA: the relative amount of the fatty acid in the total profile ( $\%$ area) changed in such a way that a constant absolute amount of $0.4 \mathrm{mg} \mathrm{gDW}^{-1}$ was recovered in mussel seed, independent from the diet. This could be an indication that the mussels have developed a mechanism to regulate the content of this fatty acid.

In addition, increasing the supplementation of MySpat from $2.8 \%$ to $4.3 \%$ to the C 3 diet had no impact on the total fat content, the total FAME content or fatty acid profile. It could be an indication of the existence of a lipid saturation level in M. galloprovincialis. Selective attainment to a steady state concentration of individual acids, with excess dietary acids being egested has been suggested for the blue mussel Mytilus edulis (Whyte et al. 2002).

Although the algae replacement is only partial, the economic benefits to mussel hatcheries of using the formulated diet MySpat are there. Producing sufficient amounts of algae for growing mussel spat at optimal rates is a real challenge. A largescale experiment in the commercial hatchery Taylor Resources Inc. demonstrated that the mussel spat grew 1.6-1.7 times faster when supplemented 1.5\% MySpat than the control animals, which received only the standard amount of mixed algae species (25-35 cells $\mu \mathrm{l}^{-1}$ at a flow rate of $6 \mathrm{~L} \mathrm{~min}^{-1}$ ). This means that the number of production cycles in a period of 6 mo can be doubled from 5 (control) to 9-9.5.

In the very near future, research will focus to what extent MySpat can replace algae without compromising growth rate and seed quality.

\section{LITERATURE CITED}

Albentosa, M., U. Labarta, A. Pérez-Camacho, M. J. Fernández-Reiriz \& R. Beiras. 1994. Fatty acid composition of Venerupis pullastra spat fed on different microalgae diets. Comp. Biochem. Physiol. 108A:639-648.

Albentosa, M., U. Labarta, M. J. Fernández-Reiriz \& A. PérezCamacho. 1996. Fatty acid composition of Ruditapes decussatus spat fed on different microalgae diets. Comp. Biochem. Physiol. 13A:113-119.

Caers, M., P. Coutteau, P. Lombeida \& P. Sorgeloos. 1998. The effect of lipid supplementation on growth and fatty acid composition of Tapes philippinarum spat. Aquaculture 162:287-299.

Coutteau, P. \& P. Sorgeloos. 1992. The use of algal substitutes and the requirement for live algae in the hatchery and nursery rearing of bivalve mollusks: an international survey. J. Shellfish Res. 11:467476.

Coutteau, P., N. H. Hadley, J. J. Manzi \& P. Sorgeloos. 1994. Effect of algal ration and substitution of algae by manipulated yeast diets on the growth of juvenile Mercenaria mercenaria. Aquaculture 120:135-150.
Davis, J. P. \& C. R. Cambell. 1998. The use of a Schizochytrium based HUFA enriched dry feed for culturing juvenile mussels (Mytilus galloprovincialis) and the comparative routine costs of producing live algae in a commercial bivalve hatchery. In: H. Grizel \& P. Kestemont, compilers. Aquaculture and water: fish culture, shellfish culture and water usage: Oostende, Belgium European Aquaculture. Society Spec. Publ. 26. pp. 65-66.

De Pauw, N. \& G. Persoone. 1988. Micro-algae for aquaculture. In: M. A. Borowitzka \& L. J. Borowitzka, editors. Micro-algal biotechnology. New York: Cambridge University Press. pp. 197221.

D’Souza, F. M. L. \& N. R. Loneragan. 1999. Effects of monospecific and mixed-algae diets on survival, development and fatty acid composition of penaeid prawn (Penaeus spp.) larvae. Mar. Biol. 133:621-633.

Edwards, E. 2004. Mussel meeting highlights big seed scarcity. Fish Farming International. October 2004. pp. 38.

EG. 1993. Richtlijn L179 voor de bepaling van ruw eiwit. Publikatieblad van de Europese Gemeenschappen. pp. 2. 
EG. 1998. Richtlijn L257 voor de bepaling van ruw vet in dierenvoeders. Publicatieblad van de Europese Gemeenschappen. pp. 23-25.

FAO Fishstat. In: Seafood international. 2006. Supplies and markets-mussels, March 2006. pp. 10.

Fernández-Reiriz, M. J., U. Labarta, M. Albentosa \& A. PérezCamacho. 2006. Lipid composition of Ruditapes philippinarum spat: effect of ration and diet quality. Comp. Biochem. Physiol. 144B:229-237.

Helm, M. M., N. Bourne \& A. Lovatelli. 2004. Hatchery culture of bivalves: a practical manual. FAO Fisheries Technical Paper 471. FAO. Rome: 177 pp.

Heras, H., J. Kean-Howie \& R. G. Ackman. 1994. The potential use of lipid microspheres as nutritional supplements for adult Ostrea edulis. Aquaculture 123:309-322.

Knauer, J. \& P. Southgate. 1997a. Assimilation of gelatin-acacia microencapsulated lipid by Pacific oyster (Crassostrea gigas) spat. Aquaculture 153:291-300.

Knauer, J. \& P. Southgate. 1997b. Growth and fatty acid composition of Pacific oyster (Crassostrea gigas) spat fed a microalga and microcapsules containing varying amounts of eicosapentaenoic and docosahexaenoic acid. J. Shellfish Res. 16:447-453.

Kreeger, D. A. \& C. Langdon. 1994. Digestion and assimilation of protein by Mytilus trossulus (Bivalvia: Mollusca) fed mixed carbohydrate/protein microcapsules. Mar. Biol. 118:479-488.

Laing, I. \& J. Lopez-Alvarado. 1994. Effect of dried algae diets on conditioning and fecundity of Manila clam, Tapes philippinarum (Adams and Reeve). Aquacult. Fish. Manag. 25:157-166.

Langdon, C. \& E. Önal. 1999. Replacement of living microalgae with spray-dried diets for the marine mussel Mytilus galloprovincialis. Aquaculture 180:283-294.

Milke, L. M., V. M. Bricelj \& C. C. Parrish. 2004. Growth of postlarval sea scallops, Placopecten magellanicus, on microalgal diets, with emphasis on the nutritional role of lipids and fatty acids. Aquaculture 234:293-317.

Nevejan, N., I. Saez, G. Gajardo \& P. Sorgeloos. 2003. Supplementation of EPA and DHA emulsions to a Dunaliella tertiolecta diet: effect on growth and lipid composition of scallop larvae, Argopecten purpuratus (Lamarck, 1819). Aquaculture 217:613-632.

Önal, E., C. Langdon \& U. Onal. 2006. The evaluation of spray-dried microalgae in diets for juvenile manila clams, Tapes philippinarum. J. Shellfish Res. 24:1061-1066.

Pernet, F., R. Tremblay, C. Langdon \& E. Bourget. 2004. Effect of additions of dietary triacylglycerol microspheres on growth, survival, and settlement of mussel (Mytilus sp.) larvae. Mar. Biol. 144:693-703.

Pérez Camacho, A., M. Albentosa, M. J. Fernández-Reiriz \& U. Labarta. 1997. Effect of microalgal and inert (cornmeal and cornstarch) diets on growth performance and biochemical composition of Ruditapes decussates seed. Aquaculture 160:89-102.

Robert, R., M.-J. Chretiennot-Dinet, R. Kaas, V. Martin-Jezequel, J. Moal, J.-R. Le Coz, J.-L. Nicolas, E. Bernard, J.-P. Connan, L. Le Dean, G. Le Gourrierec, B. Leroy \& C. Quere. 2004. Amélioration des productions phytoplanctoniques en écloserie de mollusques: caractérisation des microalgues fourrage. Rapport Ifremer DRV/ RA/RST/LPI/2004-05. 150 pp.

Whyte, J. 1987. Biochemical composition and energy content of six species of phytoplankton used in mariculture of bivalves. Aquaculture 60:231-241.

Whyte, J., K. Sherry, N. Ginther \& G. Peribere. 2002. Effects of a Schizochytrium-based diet in the growth and nutritional condition of the mussel, Mytilus galloprovincialis. Aquaculture Canada 2002 Abstracts. http://www.aquacultureassociation.ca/ac02/abstracts/ mussel.htm. 